\author{
Katarzyna Kowalik-Paluch \\ Uniwersytet Marii Curie-Skłodowskiej w Lublinie \\ ORCID - 0000-0003-4151-7957
}

\title{
WPŁYW RODZICÓW NA ROZWÓJ MOWY DZIECKA W WIEKU PRZEDSZKOLNYM
}

\begin{abstract}
Streszczenie: Artykuł przedstawia charakter wpływu rodziców na rozwój mowy dziecka. Zawiera charakterystykę mowy dziecka w okresie przedszkolnym. Artykuł pozwala również odpowiedzieć na pytanie, w jaki sposób rodzice lub inne podmioty odpowiedzialne za dziecko, mogą wspomóc prawidłowy rozwój jego mowy.
\end{abstract}

Słowa kluczowe: mowa, rodzice, rozwój mowy, dziecko w wieku przedszkolnym

\section{WPROWADZENIE}

Nauka mowy to wyzwanie, z jakim musi się zmierzyć dziecko. Zazwyczaj udaje się to w kilku pierwszych latach życia człowieka, zanim jeszcze rozpocznie edukację w ramach szkolnictwa zinstytucjonalizowanego. Wygenerowanie tak złożonego systemu lingwistycznego oraz umiejętność sprawnego i poprawnego posługiwania się nim to dobre uzasadnienie wyjątkowości rodzaju ludzkiego. Literatura przedmiotu upatruje pierwocin kształtowania się języka w różnych teoriach: teorii uczenia się, w której zasadniczą rolę odgrywa wpływ najbliższego otoczenia oraz modelowanie i wzmacnianie. Psycholingwistyka natomiast przypisuje źródło nabywania sprawności językowych biologii. Warto wspomnieć, że mimo różnorodności teorii zdolności językowe są charakterystyczne i jednorakie dla gatunku ludzkiego (Bugajski 2007; Kurcz, Okuniewska 2011). Racjonalne zatem wydaje się stanowisko holistycznie rozpatrujące tę kwestię. Bez względu jednak na przyjęty pogląd badacze zgadzają się ze sobą, że kształtowanie mowy ma przebieg długotrwały i etapowy. Jedni uważają, że zaczyna się już w chwili wydania pierwszego krzyku przez dziecko, czyli tuż po narodzinach, inni sądzą, że ma to miejsce jeszcze w okresie płodowym człowieka. 
Analizując w ujęciu teoretycznym oraz praktycznym temat zawarty w tytule pracy, zajmę się przyswajaniem mowy przez dziecko w środowisku rodzinnym, gdzie mentorem młodego człowieka w nauce poprawnego komunikowania się ze światem powinni być przygotowani do tej roli rodzice. Problem pojawia się, gdy rodzice nie są na tyle dojrzali, by sprostać tak odpowiedzialnemu zadaniu lub kiedy w wyniku sytuacji losowej, dziecko pozostaje pod opieką innych bliskich. W takiej sytuacji to na ich barkach spoczywa obowiązek wprowadzenia dziecka w świat mowy.

\section{MOWA DZIECKA W WIEKU PRZEDSZKOLNYM}

Człowiek przychodząc na świat, jest istotą bezbronną, uzależnioną całkowicie od innych. Posiada zasób prymitywnych aktywności, które pomagają mu w kontakcie ze światem zewnętrznym. Jednakże dopiero harmonijny rozwój mowy przyczynia się do podnoszenia wartości komunikacji międzyludzkiej. Ma to miejsce w wieku przedszkolnym. Wtedy to także dziecko poszerza swoje zdolności poznawcze, emocjonalne oraz możliwości fizyczne. Wiek przedszkolny to czas przyswajania mowy oraz wykorzystywania jej w celu opisywania postrzegania siebie, innych osób oraz świata. To okres opanowania reguł generowania sensownych wypowiedzi, poprawnych pod względem gramatycznym. Zgodzę się zatem z Jolantą Olkusz, która zauważa, że wiek od 3. do 6. roku życia to rozkwit mowy dziecka, który umożliwia pełne funkcjonowanie młodego człowieka w społeczeństwie (Olkusz 2014, s. 16-19). To czas, w którym zdobywa ono przygotowanie językowe, komunikacyjne i kulturowe niezbędne do otwartej dyskusji (Grabias 1997, s. 33-34). Dynamiczny rozwój mowy w okresie przedszkolnym zauważyła także Joanna Metejczuk, wspominając w pracy Rozwój dziecka. Wiek przedszkolny (Metejczuk, 2014, s. 46) o możliwościach komunikacyjnych dziecka w wieku od 3 do 6 lat. Autorka akcentuje wpływ doświadczeń przedwerbalnych oraz werbalnych młodego człowieka jeszcze z czasów niemowlęctwa i wczesnego etapu dzieciństwa. Zatem należy w tym miejscu przyjrzeć się fazie przyswajania mowy przez dziecko w okresie przedszkolnym. Literatura podaje, że rozwój mowy dziecka zasadniczo można podzielić na cztery etapy. Stadia te nie są jednak wyraziście zróżnicowane, lecz umożliwiają usystematyzować w czasie wstępne oznaki werbalizacji (Kurcz 2005, s. 84). Prekursorem podziału mowy na etapy (melodii, wyrazu, zdania, swoistej mowy dziecięcej), jak również twórcą logopedii na gruncie polskim był Leon Kaczmarek (1953). Choć od wspomnianego czasu minęło już pół wieku, kolejni badacze nadal bazują na dokonaniach Kaczmarka (Zarębina 1994; Twardowski 2007; Skorek 2008). Trudno ukazać w kilku zdaniach proces rozwoju mowy dzie- 
cka przedszkolnego, gdyż okres ten obejmuje aż 3 lata jego życia i jest tym samym najdłuższym etapem w rozwoju mowy. Kolejny problem stanowi także wspomniana wcześniej płynność granic poszczególnych okresów rozwoju mowy. Jednak na potrzeby pracy dokonam spójnej analizy mowy w okresie swoistej mowy dziecięcej $\mathrm{w}$ ujęciu teoretycznym oraz praktycznym, bazując na badaniach $\mathrm{z}$ tego zakresu.

Początek wieku przedszkolnego, czyli 3. rok życia, to doskonalenie wcześniej zdobytych umiejętności w zakresie mowy, czyli prawidłowa artykulacja spółgłosek zębowo-wargowych $f, f i, w, w i$, wargowych $p, p i, b, b i, m, m i$, środkowojęzykowych ś, $\dot{z}, \dot{c}, d \dot{z}, \dot{n}, k i, g i$ oraz tylnojęzykowych $k, g$, $h$. Przełom 4 . i 5. roku życia dziecka to nabywanie umiejętności artykulacji głosek $s, z, c, d z, r, s z, c z, \dot{z}, d \dot{z}$. Pełna świadomość artykulacyjna wiąże się ściśle z prawidłowym artykułowaniem poszczególnych dźwięków mowy (Rittel 2015, s. 60), dlatego też dziecko w wieku przedszkolnym na bazie posiadanych umiejętności językowych cechuje się dużą świadomością wokalizacyjną (Wasilewska, Szafran 2012, s. 130). W jaki sposób można to rozumieć? Dziecko rozpoczynające edukację przedszkolną nie jest w stanie wyartykułować poprawnie niektórych głosek, wie natomiast, w jaki sposób powinny brzmieć oraz właściwie je rozpoznaje. Wiedza teoretyczna przekształca się na umiejętności praktyczne w późniejszych latach okresu przedszkolnego.

Dziecko kończące edukację przedszkolną charakteryzuje się właściwie ukształtowanym aparatem artykulacyjnym oraz zdolnością intuicyjnego stosowania gramatyki języka ojczystego.

Omawiając rozwój mowy, warto pamiętać o równoważnikach zdań poprzedzających samoistną mowę dziecka. Wypowiedzi dzieci przedszkolnych obfitują także w wyrazy kontaminacyjne (utworzone przez połączenie dwóch lub trzech innych wyrazów) oraz neologizmy. Neologizmy dziecięce badała jeszcze w latach 70. XX wieku Maria Chmura-Klekotowa. Wyniki jej badań potwierdziły powszechność neologizmów wśród dzieci oraz ukazały występowanie różnych rodzajów neologizmów dziecięcych, które wiązały się z aktywnością słowotwórczą podczas nazywania rzeczy lub zjawisk (Chmura-Klekotowa 1971, s. 99-235). Mimo że od badań autorki minęło już ponad 45 lat, można śmiało stwierdzić, że to zagadnienie nadal jest chętnie zgłębiane przez współczesnych logopedów i językoznawców (Haman, Kochańska, Łuniewska, Smoczyńska 2014; Muzyka-Furtak 2011). Warto skupić uwagę również na dokonaniach Ewy Muzyki-Furtak, która badała dzieci niesłyszące metodą eksperymentu, mimo to wpłynęła znacznie na rozwój wiedzy dotyczącej przyswajania mowy przez dzieci, których aparat słuchu jest właściwie rozwinięty. Autorka sugeruje, że neologizmy dziecięce pomimo tego, iż są tworzone na kanwie innego wyrazu niż wyraz o charakterze podstawowym, dają dowód na kreatywność językową dziecka oraz wysoki poziom opanowania środków słowotwórczych (Muzyka-Furtak 2011, s. 126). Można zatem mniemać, 
że pojawianie się neologizmów w mowie dziecka świadczy o nabywaniu umiejętności gramatycznych języka ojczystego oraz chęci, by tę wiedzę, w sposób niekontrolowany, a kreatywny, zastosować w praktyce. To także dowód na to, że przedszkolak stosuje język i określone reguły jego użycia zarówno do określania siebie, swych myśli i planów, jak i do określania otaczającej go rzeczywistości. Produktywność powstawania neologizmów jest charakterystyczna dla dzieci w wieku przedszkolnym. Później umiejętność ta powoli słabnie, by w wieku dorosłym zaniknąć całkowicie (Kamińska, Siebert 2012, s. 241). Dlaczego zatem dziecko tworzy neologizmy? Nasuwa się w tym miejscu główny powód. Dziecko chce zrekompensować uczucie dysonansu pomiędzy obecnym poziomem swoich możliwości komunikacyjnych, a aktualną potrzebą użycia słowa, którego nie ma jeszcze w indywidualnym zasobie słownika czynnego.

Wiek przedszkolny to czas wzmożonej eksploracji świata. Rośnie wtedy ciekawość dziecka dotycząca otoczenia. Formą zaspokajania spontanicznej ciekawości poznawczej są pytania dziecięce. Początkowo pełnią funkcję poznawczą. Błędem byłoby jednak pominiecie równie istotnej drugiej funkcji wieku pytań dziecka pracy nad oddzieleniem świata realnego od fantazji. Trzecia przyczyna zadawania wielu pytań przez dziecko i powtarzania tych samych pytań jest dosyć prozaiczna. Dziecku bowiem chodzi o podtrzymanie kontaktu ze swoim rozmówcą. Pytania stanowią dobrą okazję do zabaw i ciekawych dyskusji, możliwych jedynie gdy obie strony są chętne i otwarte na podejmowane działania. Zatem dziecko, spotykając się z milczeniem rodzica lub też głośnym sprzeciwem wobec tworzenia odpowiedzi na kolejne pytanie, traci powoli ochotę na generowanie nurtujących pytań, przez co kontakt $\mathrm{z}$ rodzicem również słabnie.

Rozważając kwestię mowy dziecka, nie można pozostać obojętnym wobec jego emocji. Warto przyjrzeć się stanowisku Agnieszki Lasoty, które przedstawiła w pracy Specyficzne zaburzenia rozwoju językowego (Lasota 2007, s. 40). Wskazuje w niej na pojawiające się na początku edukacji wczesnoszkolnej dysfunkcje logopedyczne, które figurują w Międzynarodowej Statystycznej Klasyfikacji Chorób i Problemów Zdrowotnych pod symbolem F80 jako Specyficzne zaburzenia rozwoju mowy i języ$k a$, tworząc tym samym podkategorię Zaburzeń rozwoju psychologicznego (2008, s. 39). Zatem racjonalne wydaje się stwierdzenie, że prawidłowy rozwój mowy koreluje z właściwym kształtowaniem sfery psychologicznej człowieka, włączając w nią również emocje. Jest to jednak pewne uproszczenie. Nie można bowiem bezdyskusyjnie stwierdzić, że dziecko przejawiające problemy w zakresie emocji nie jest w stanie właściwie posługiwać się mową w komunikacji międzyludzkiej. Każde badania prowokują do kolejnych pytań, na które badacze chętnie będą poszukiwali odpowiedzi. Logopedzi zgodnie twierdzą, że rozwój mowy dziecka rozpoczynającego edukację wczesnoszkolną powinien być już sfinalizowany. Jednak 
nie wszystkie dzieci mają ku temu jednakowo komfortowe szanse, biorąc pod uwagę między innymi środowisko wychowawcze, z jakiego pochodzą. Mając na uwadze kolejną część rozważań, warto zatrzymać się przy sentencji Peggy O’Mara, która w jednym zdaniu uchwyciła sens komunikacji pomiędzy rodzicami a dzieckiem: „The way we talk to our children becomes their inner voice”(O’Mara 2005, 8-12).

\section{RODZICE A ROZWÓJ MOWY DZIECKA}

Od początku życia dziecka na barkach rodziców spoczywa duża odpowiedzialność związana z nauką, wychowaniem i opieką potomstwa. Rodzice jeszcze przed rozpoczęciem edukacji zinstytucjonalizowanej zaopatrują dziecko w wiedzę i umiejętności niezbędne do integralnej egzystencji w społeczeństwie. Do zadań rodziców należy także podejmowanie działań mających na celu świadome zwiększanie kompetencji komunikacyjnych dziecka. Styl mowy dziecka zależy od jakości komunikacji pomiędzy rodzicami. Jest to jednak spore uproszczenie. Nie można bezwarunkowo założyć, że mowa dziecka jest odbiciem mowy jedynie jego rodziców. W sytuacji gdy rodzice nie mogą lub też nie chcą uczestniczyć w życiu dziecka, obowiązki rodziców w zakresie sprawowania odpowiedzialnej opieki nad dzieckiem przejmują inne osoby znaczące $\mathrm{z}$ rodziny, wspierane przez zinstytucjonalizowane placówki.

Magdalena Wasilewska analizując w swych badaniach przypadki indywidualne dzieci przedszkolnych, przedstawia dosyć wyraźnie zależności pomiędzy kodem językowym stosowanym przez rodziców, charakterem opieki nad dzieckiem przed rozpoczęciem edukacji przedszkolnej a rozwojem mowy dziecka (Wasilewska 2006, s. 8). Na podstawie badań Wasilewskiej można wysunąć wnioski, które przyczynią się do zwiększenia świadomości rodziców w zakresie stwarzania warunków optymalnych, wpływających na jakość i harmonijny rozwój mowy dziecka. Wasilewska dowodzi, jak ważne dla płynnego rozwoju mowy jest również zachęcanie dziecka do dzielenia się swoimi doświadczeniami, przemyśleniami czy też zwykłymi sytuacjami z życia codziennego. Zatem rodzice, dla których rozwój mowy dziecka stanowi ważne wyzwanie rodzicielskie, powinni unikać kodu ograniczonego na rzecz kodu rozwiniętego, pamiętając, że dziecko uczy się mowy poprzez naśladownictwo (Olechnicki, Załęcki 1997, s. 95). Podążając tym tokiem rozumowania, łatwo sformułować konkluzję, będącą potwierdzeniem wcześniejszych myśli: dziecko, które wzrasta w atmosferze miłości, szacunku i bezpieczeństwa, w domu, gdzie rodzice stale komunikują się, stosując kod rozwinięty, pozbawiony stereotypów, a bogaty w logiczną argumentację, ma zwiększone szanse na szybsze i poprawne przyswajanie mowy. 
Jednak Szafrańska i Wasilewska wskazują zgodnie korelacje pojawiające się w wynikach badań, które negują powyższe stwierdzenie. Ich zdaniem kod rozwinięty stosowany przez rodziców nie wpływa tak istotnie na jakość mowy, jak związek pomiędzy ograniczonym, i z pozoru niekorzystnym, kodem językowym rodziców a dobrą opieką nad dzieckiem. Zanim przejdę do kolejnej części rozważań, pragnę zastanowić się nad źródłem tego typu wniosków. Dlaczego ograniczony kod językowy stosowany przez rodziców uczestniczących w badaniach nie wpływa negatywnie na rozwój mowy dziecka? Sądzę, że jest ku temu kilka powodów. Po pierwsze świadomi rodzice $\mathrm{w}$ kontaktach $\mathrm{z}$ pedagogami i logopedami będą starali się poprawić jakość własnych zdolności językowych, przez co wpłyną również na poziom rozwoju mowy swoich dzieci. Skutkuje to zmianą wzorców wymowy dziecka pomimo pozornie niesprzyjającego dla jakości wymowy otoczenia. Badania pokazały również inną zależność związaną ze stosowaniem prostego kodu językowego przez rodziców oraz włączanie do wypowiedzi zdrobnień, nazw zastępczych, np. hau-hau. Taki rodzaj działań podjęty przez rodziców nie wpływa pozytywnie na rozwój mowy dziecka, które „zmuszane” jest do podwójnego wysiłku. Warto bowiem zwrócić uwagę na dwa mechanizmy językowe, jakim musi sprostać dziecko. Pierwszy z nich to nauka zniekształconej formy języka, którą dziecko przyswaja od rodziców. Drugi natomiast to nauka mowy poprawnej. Jest to proces moim zdaniem trudniejszy, gdyż nazwy, którymi dziecko się posługiwało, nie pasują do przedmiotów, zjawisk, osób, czyli desygnatów.

Uwagę badaczy skupia również formułowanie infantylnych zwrotów w kontaktach z dziećmi. Jedni z nich przyjmują stanowisko, że stosowane zdrobnienia pomagają dziecku na drodze do przyswajania mowy, inni z kolei sądzą, że formy infantylne to błędy językowe. Badania naukowe dotyczące wypowiedzi dorosłych kierowanych do dzieci $z$ ostatnich lat przypisują jednak formom infantylnym pozytywny wpływ na rozwój mowy dziecka. Milewski podkreśla, że wspomniane formy dostosowane są do poziomu rozwoju poznawczego dziecka w tak wczesnej fazie rozwoju, jak okres poprzedzający wychowanie przedszkolne (Milewski 2004, s. 127-132). Stanowią znaczne ułatwienie na drodze do osiągnięcia pełnej sprawności poprawnego posługiwania się mową. Haman podkreśla jednoznacznie, że gdy stają się one zbyteczne, zanikają w mowie (Haman 2014, s. 4). Stanowisko przeciwne zajmuje m.in. Agata Hącia, która opowiadająca się za negatywnym wpływem zwracania się do dzieci z użyciem form infantylnych. Warto zastanowić się nad powszechnością stosowania tych form. Hącia podkreśla, że wynikają one z dobrych pobudek, jednak przynoszą wiele krzywdy samemu dziecku w postaci opóźnień rozwoju mowy ${ }^{1}$. Dziecko po pewnym czasie zauważa, że zwroty kierowane

${ }^{1}$ Hącia A. Dlaczego dorośli seplenią mówiąc do dzieci? http://www.polskieradio.pl/10/484/ Artykul/377821,Dlaczego-dorosli-seplenia-mowiac-do-dzieci [dostęp: 31.03.2017]. 
do niego, różnią się od tych, które rodzice mówią do innych członków rodziny lub osób mniej znaczących. Skutkuje to utwierdzaniem się dziecka w przekonaniu, że jest inne i odbiega znacząco od świata dorosłych. Dziecko czuje podświadomie, że ma ograniczony dostęp do świata dorosłych.

Jednak nie zawsze sytuacja rodzinna dziecka jest tak optymalna i z tego też powodu nie wszystkie dzieci posiadają zbliżony zasób językowy. Jednak błędne i dosyć krzywdzące dla niektórych rodziców byłoby stwierdzenie, że ich pochodzenie wpływa negatywnie na jakość mowy ich potomstwa. Rodzice nie mają możliwości zmiany miejsca, z którego pochodzą, czy też wartości, jakie zostały im wdrożone w domach rodzinnych. Jednak dla dobra dziecka opiekunowie mogą realizować szerokie działania, które wpłyną na poprawę jakości komunikacji na linii rodzic- rodzic oraz rodzice - dziecko. Jednym ze wspomnianych działań są częste rozmowy z dzieckiem, podczas których maluch uczy się nowych słów, wzbogacając tym samym swój słownik bierny oraz czynny (Wasilewska, Szafran 2012, s. 133). Można w tym miejscu zastanowić się nad sytuacją odwrotną, rozgrywającą się w środowisku rodzinnym, gdzie rodzice nie wykazują inicjatywy w podejmowaniu rozmów z dzieckiem. Skutkuje to poczuciem wyobcowania i odtrącenia przez osoby najbliższe. Należy pamiętać o tym, że również we wskazanym przypadku dziecko uczy się zachowań przez modelowanie, jednak w tej sytuacji wpływa to niekorzystnie na rozwój mowy dziecka.

Rodzice przebywają z dzieckiem zazwyczaj dużo czasu. By zapewnić harmonijny rozwój mowy swojego dziecka, powinni dobrze wykorzystywać dostępny czas i swoje możliwości, których jest dosyć dużo. W dalszej części artykułu wymienię kilka form rozwijania mowy u dziecka.

\section{CZYTANIE BAJEK}

O zbawiennej roli czytania dla rozwoju mowy dziecka wydano już wiele pozycji naukowych (Jakubowska, Lenartowicz, Plenkiewicz 1999; Molicka 2002; Huszcz, Cichoń, Piasecka 2003; Truskolaska 2007). Podejmują one próbę ukazania zalet głośnego czytania bajek dziecku.

Niemniej moją uwagę przykuł raport Badanie efektów czytania dzieciom od urodzenia utworzony przez Fundację ABCXXI Cała Polska czyta dzieciom opublikowany w 2015 roku. Badanie miało formę ankiety elektronicznej i stanowiło wstęp do długoletnich badań planowanych na 15-20 lat. Celem badania było poznanie ewentualnych zależności pomiędzy czytaniem bajek dziecku od urodzenia przez rodziców i rozwojem dziecka w różnych obszarach, w tym także rozwój mowy. W badaniu elektronicznym wzięło udział 2500 respondentów (głównie 
matki dzieci przed rozpoczęciem edukacji przedszkolnej). Odbywało się w pięciu turach. Wyniki badań potwierdziły, jak znaczące wartości niesie ze sobą czytanie książek dla rozwoju mowy dziecka już od pierwszych miesięcy jego życia. Z badań opublikowanych w 2015 roku wynika bowiem:

1. Mowa bierna i czynna dziecka rozwija się prawidłowo, jednak wiek dzieci nie pozwalał jednoznacznie określić poziomu słownictwa czynnego. Dlatego też autorki sugerują przeprowadzenie kolejnych badań w grupie respondentów $\mathrm{w}$ wieku przedszkolnym.

2. Większość dzieci, zdaniem rodziców, rozumie słowa użyte w badaniu.

3. Znaczna większość rodziców uważa, że pozytywne skutki czytania od najmłodszych lat życia dziecka będą widoczne już na etapie edukacji przedszkolnej i wczesnoszkolnej (Pogoda, Szostakowska, Szczurek 2015, s. 2-4).

Zgodzę się z autorkami i organizatorkami badania, które proponują jego powtórzenie, gdy dzieci będą wchodziły w wiek wczesnoszkolny. Ukaże to miarodajny wpływ czytania bajek na rozwój sprawności językowych.

Moje własne doświadczenia zdobyte podczas pracy w przedszkolu w różnych grupach wiekowych pokrywają się z praktyką Fundacji w obszarze rozwoju mowy współczesnych dzieci. Uważam bowiem, że jakość mowy przedszkolaków jest coraz gorsza. Zdaniem Fundacji oraz prowadzonych przeze mnie obserwacji dzieci, rozmów z dziećmi i ich rodzicami do tego stanu głównie przyczynia się mniejsza ilość okazji do słuchania zarówno mówiących, jak i czytających im rodziców.

Warto przyjrzeć się także rozmowom indywidualnym rodziców z dzieckiem. Idąc do pracy, słyszę nieraz barwne opowieści rodziców o przyczynie opadania liści z drzew czy też śladach psich łap na śniegu. Takie dyskusje napełniają mnie radością i nadzieją, że współcześnie rodzice potrafią jeszcze mówić do dziecka i wsłuchiwać się w dziecko. Spotyka mnie nieraz mniej miłe zaskoczenie, gdy jestem świadkiem niemych spacerów odbywających się w dystansie pomiędzy dzieckiem i rodzicem. Te luźne przemyślenia nie mogą stanowić podstaw do rzetelnego wnioskowania o przyczynach tego zjawiska. Pozostawiam to do rozmyślań rodziców oraz badaczy, którzy zechcą zgłębić przyczyny i konsekwencje takiego stanu rzeczy. Jednak ja wysunę śmiałą tezę stanowiącą dobry materiał do badań. Sądzę, że takie nieme bycie z dzieckiem nie wpływa stymulująco na rozwój jego mowy. Bowiem dziecko nie doświadcza wtedy wzorca poprawnej mowy, nie rozwija swojego słownika biernego i czynnego. Pozostają więc inne, alternatywne możliwości stymulowania mowy dziecka. 


\section{ZABAWY, GRY JĘZYKOWE, PIOSENKI, WYLICZANKI, RYMOWANKI}

Rodzice jako osoby najbliższe dziecku mają do dyspozycji także inne warianty wpływu na harmonijny rozwój mowy dziecka, m.in. zabawy i gry językowe. Natalia i Krzysztof Minge w swej pracy Jak kreatywnie wspierać rozwój dziecka? (Minge 2011) sympatyzują z Colin Rose i Gordonem Dryder (Rose, Gordon 2010, s. 10) w kwestii wykorzystywania różnych sytuacji domowych jako okazji sprzyjających nabywaniu przez dziecko wartościowych doświadczeń, w tym również tych, które przyczynią się do rozwoju mowy dzieci. Dziecko biorąc udział w zabawach słownych, osłuchuje się z językiem i zaczyna bawić się słowem, a jak powszechnie wiadomo to właśnie zabawa powinna być główną aktywnością podejmowaną przez dziecko przedszkolne (Gruszczyk-Kolczyńska, Zielińska 2004, s. 32). To nie koniec zalet zabaw językowych. Rodzice świadomi możliwości, jakimi dysponują w kwestii stymulowania mowy swojego dziecka, wpływają na szybkość i jakość poznawanego przez dzieci słownictwa i zwrotów charakterystycznych dla języka ojczystego. Dodatkowo dzieci kształtują percepcję i pamięć słuchową.

\section{PRACA Z OBRAZKIEM}

Rodzice sięgający po historyjkę obrazkową mają w swoich dłoniach narzędzie stymulujące rozwój mowy dziecka. Rola rodzica nie ogranicza się do przedstawiania dzieciom kolorowych obrazków. Jako świadomy nauczyciel i wychowawca rodzic powinien kierować uwagę dzieci na rozpoznawanie i przypominanie nazw przedmiotów, zjawisk, osób znajdujących się na ilustracji. Warto uwzględnić także sposób i poziom ingerencji rodzica w wypowiedź dziecka. Powinien on konsekwentnie korygować błędy pojawiające się w wypowiedziach dziecka w sposób wyważony, by poprzez wyśmianie czy zażartowanie z dziecka nie zaprzestało ono podejmowania dalszych aktywności werbalnych. Praca z historyjką obrazkową wspomaga proces analizy, gdyż zadaniem dziecka jest próba „odczytania” treści zawartej na obrazkach, dostrzeżenie różnic i podobieństw pomiędzy obrazkami (Fisher 1999, s. 69). Nie sposób doszukać się jakichkolwiek wad w pracy metodą historyjki obrazkowej. Jednak rodzice zauważą jedną, która wystarczy im, by zaniechać podjęcia pracy z dzieckiem- jest nią konieczność poświęcenia przez rodzica drogocennego czasu. Niedogodność tę zostawiam do oceny czytelnikowi. 


\section{PODSUMOWANIE}

Jakość mowy dziecka ma duży wpływ na ogólny rozwój intelektualny oraz jego osobowość. Dzięki mowie dziecko odbiera otaczający je świat, wpływa na myślenie, które niezbędne jest do planowania podejmowanych aktywności. Można zauważyć ciekawą zależność, bowiem dziecko poznaje i uczy się świata także dzięki mowie, również dzięki mowie świat poznaje emocje dziecka, jego potrzeby i myśli. Dobre warunki dla rozwoju mowy mogą stworzyć dziecku jego rodzice, inne osoby bliskie oraz środowisko przedszkolne. Dom i przedszkole to środowiska, w których dziecko spędza zazwyczaj najwięcej. Stąd też czerpie wzorce mowy. Rodzice posiadają szeroką gamę możliwości stymulujących mowę dziecka - od pozwolenia dziecku na swobodne wyrażanie swoich myśli, sądów, opinii, pragnień, poprzez czytanie dziecku bajek, opowiadań, do pracy poprzez zabawę w formie historyjek obrazkowych, plansz edukacyjnych, rebusów, zabaw słownych.

Mowie wtórują także emocje, stanowiące istotny element wypowiedzi dziecka. Dobrze jest, gdy dziecko uczy się języka w codziennych sytuacjach w rodzinie przy boku rodziców i bliskich. Czuje wtedy komfort i poczucie bezpieczeństwa co wspomaga przyswajanie nowego słownictwa i umiejętności swobodnego komunikowania się z domownikami, rówieśnikami oraz osobami obcymi: „Dzięki komunikowaniu się $\mathrm{z}$ innymi $\mathrm{w}$ różnych sytuacjach, dzieci czerpią pomysły na posługiwanie się językiem od rówieśników, obserwują ich reakcje na własny język, odczuwają w bezpośrednich kontaktach, jak inni używają języka" (Żytko 2010, s. 8). Bez względu na rodzaj podmiotu, który organizuje proces nabywania umiejętności mówienia należy pamiętać, by działalność ta miała charakter świadomy, przemyślany i dobrze zorganizowany.

\section{LITERATURA}

Bugajski M., 2007, Język w komunikowaniu. Warszawa, Wydawnictwo Naukowe PWN. Chmura-Klekotowa M., 1971, Neologizmy słowotwórcze w mowie dzieci. „Prace Filologiczne" XXI.

Fisher R., 1999, Uczymy, jak myśleć. Warszawa, Wydawnictwa Szkolne i Pedagogiczne. Grabias S., 1997, Język w zachowaniach społecznych. Lublin, Wydawnictwo UMCS. Gruszczyk-Kolczyńska E., Zielińska E., 2004, Wspomaganie rozwoju umysłowego czterolatków i pięciolatków: książka dla rodziców, terapeutów i nauczycieli przedszkola. Warszawa, Wydawnictwa Szkolne i Pedagogiczne.

Haman E., Kochańska M., Łuniewska M., Smoczyńska M., 2014, Mowa dziecka i jak rodzice moga wspierać jej rozwój? Warszawa, Instytut Badań Edukacyjnych. 
Huszcz M., Cichoń-Piasecka M., 2003, Baśnie uczq życiowych ról. „Wychowanie w Przedszkolu”, nr 10.

Jakubowicz A., Lenartowska K., Plenkiewicz M.,1999, Czytanie w początkowych latach edukacji. Bydgoszcz, Logos-Logistyka sp. z o.o.

Kaczmarek L., 1953, Kształtowanie mowy dziecka. Poznań, PTPN.

Kamińska B., Siebert B., 2012, Podstawy rozwoju mowy u dzieci. „Wybrane Problemy Kliniczne”, nr 5.

Kurcz I., 2005, Psychologia języka i komunikacji. Warszawa, Wydawnictwo „Scholar”. Kurcz I., Okuniewska H., 2011, Język jako przedmiot badań psychologicznych. Psycholingwistyka ogólna i neurolingwistyka. Warszawa, SWPS.

Lasota A., 2007, Specyficzne zaburzenia rozwoju językowego. „Sztuka Leczenia”, nr 1-2. Matejczuk J.,2014, Rozwój dziecka. Wiek przedszkolny. W: A.I. Brzezińska (red.), Niezbędnik dobrego nauczyciela. Warszawa, Instytut Badań Edukacyjnych.

Metejczuk J., 2014, Środowisko rozwoju dziecka w wieku przedszkolnym: potrzeby dziecka a jakość rodzinnej i poza rodzinnej oferty edukacyjnej. W: A.I. Brzezińska, J. Matejczuk, P. Jankowski, M. Rękosiewicz (red.), 6-latki w szkole-rozwój i wspomaganie rozwoju. Poznań, Wydawnictwo Fundacji Humaniora.

Międzynarodowa Statystyczna Klasyfikacja Chorób i Problemów Zdrowotnych. Rewizja dziesiąta, 2008, Word Health Organization, Centrum Systemów Informacyjnych Ochrony Zdrowia.

Milewski S., 2004, Mowa dorostych kierowana do niemowląt. Studium fonostatystycznofonotaktyczne. Gdańsk, Wydawnictwo UG.

Minge N., Minge T., 2011, Jak kreatywnie wspierać rozwój dziecka? Warszawa, Edgard. Molicka M., 2002, Bajkoterapia - o lękach dzieci i nowej metodzie terapii. Poznań, Media Rodzina.

Muzyka-Furtak E., 2011, Konstrukcje słowotwórcze a kategorie poznawcze dzieci niesłyszących. „Język a Kultura”, nr 22.

O’Mara P., 2005, A Lantern for Lori. „Mothering Magazine”, nr 128.

Olechnicki K., Załęcki P., 1997, Słownik socjologiczny, Toruń, Graffiti.

Olkusz J., 2014, O budowaniu świadomości językowej. „Wychowanie w Przedszkolu”, nr 1. Olkusz J., 2014, O budowaniu świadomości językowej. „Wychowanie w Przedszkolu”, nr 1. Pogoda I., Szostakowska M., Szczurek A., 2015, Badanie efektów czytania dzieciom od urodzenia. Warszawa.

Rittel T. i S.J., 2015, Dyskurs edukacyjny. Zagadnienia - znaczenia - terminy. Wybór i opracowanie. Kraków, Collegium Columbinum.

Rose C., Gordon D., 2010, Jakpostępować, żeby zapewnić dziecku wszechstronny rozwój? „Wielka Zabawa. Magazyn dla rodziców dzieci najmłodszych”, nr 1.

Skorek E.M., 2008, Zaburzenia mowy a stosunki koleżeńskie dzieci. Kraków, Oficyna Wydawnicza „Impuls”. 
Truskolaska J., 2007, Wychować miłośnika książki, czyli czytelnictwo i okolice. Tychy, Maternus Media.

Twardowski A., 2007, Porozumiewanie się dorosłego z dzieckiem. „Wychowanie w Przedszkolu", nr 6.

Wasilewska M., 2006, Psychospołeczne podstawy rozwoju mowy dzieci 3-5 letnich. Poznań, Centrum Demostenes.

Wasilewska M., Szafran J., 2012, Rozwój mowy dzieci 3-5-letnich. Podstawy psychospołeczne-analiza przypadków. „Dodatek psychologiczny. Wiadomości Psychiatryczne", tom 15, nr 3, lipiec-wrzesień 2012.

Zarębina M., 2004, Język polski w rozwoju jednostki. Analiza tekstów dzieci do wieku szkolnego. Rozwój semantyczny języka dziecka. Gdańsk, Wydawnictwo Glottispol.

Żytko M., 2010, Pozwólmy dzieciom mówić i pisać - w kontekście badań umiejętności językowych trzecioklasistów. Warszawa.

Źródło internetowe:

Hącia A., Dlaczego dorośli seplenia mówiąc do dzieci?, opublikowano w: http://www. polskieradio.pl/10/484/Artykul/377821,Dlaczego-dorosli-seplenia-mowiac-dodzieci [dostęp: 31.03.2017].

\title{
THE INFLUENCE OF PARENTS ON THE SPEECH DEVELOPMENT \\ OF A PRESCHOOL CHILD
}

\begin{abstract}
The article aims at character of the influence of parents on the development of the baby talk. It contains the characterization of the baby talk in the pre-school period. This paper helps to answer a question of what way parents or the other operators responsible for the child, can support the normal development speeches of child.
\end{abstract}

Keywords: speech, parents, development of the speech, kindergarten pupil 